\title{
INHIBIN SECRETION DURING THE RAT ESTROUS CYCLE: RELATIONSHIPS TO FSH SECRETION AND FSH BETA SUBUNIT MRNA CONCENTRATIONS
}

\author{
DJ Haisenleder, GA Ortolano, D Jolly*, 1AC Dalkin, TD Landefeld \\ 3 WW Vale* and 2JC Marshall
}
Division of Endocrinology and Metabolism, Department of Internal Medicine, and Pharmacology, University of Michigan, Ann Arbor, Michigan 48109 *Clayton Foundation Laboratories for Peptide Biology, The Salk Institute La Jolla, California 92037

(Received In final form September 6, 1990)

\section{Summary}

Serum inhibin and FSH and FSH beta subunit mRNA levels were measured at $3 \mathrm{~h}$ intervals throughout the 4 day estrous cycle in female rats and hourly between 1000 and $2400 \mathrm{~h}$ of proestrus. On proestrus, serum inhibin concentrations fell during the late morning-early afternoon, then increased transiently during the late afternoon gonadotropin surges. Inhibin levels decreased during the late evening of proestrus, coincident with the FSH surgerelated rise in FSH beta mRNA levels. Serum inhibin remained relatively stable during estrus and early metestrus, but rose during the late evening of metestrus and remained elevated until early diestrus. FSH beta mRNA levels were elevated on late estrus and early metestrus and declined during the evening of metestrus as serum inhibin levels increased. These data show that concentrations of serum inhibin change during the estrous cycle and that a general inverse relationship exists between serum inhibin and FSH levels and FSH beta mRNA concentrations in the pituitary. This suggests that inhibin may inhibit FSH beta gene expression and FSH secretion during the 4 day cycle in female rats.

The pattern of gonadotropin secretion during the 4 day rat estrous cycle has previously been characterized (1-4). On proestrus, a preovulatory surge of luteinizing hormone (LH) occurs during the late afternoon. Follicle stimulating hormone (FSH) also expresses a surge on proestrus, but this has a biphasic nature and evidence suggests that it is controlled by different mechanisms. Prior work has shown that the first phase of FSH release (as well as LH) is stimulated by an increase in pulsatile secretion of the hypothalamic peptide gonadotropinreleasing hormone $(\mathrm{GnRH})(5,6)$. The secondary FSH surge appears to be regulated by ovarian inhibin $(7,8)$. Inhibin is a glycoprotein composed of 2 subunits, alpha and beta (9). Inhibin has been shown to suppress FSH secretion (10-12) and FSH beta gene expression (1214) by a direct action on the gonadotroph cell.

We recently characterized the changes in pituitary FSH beta mRNA during the rat estrous cycle to increase our understanding of the physiological relationship between FSH secretory activity and gene expression (15). Serum samples collected in that study were used to measure serum inhibin concentrations in order to establish the relationships between serum inhibin and FSH secretion and FSH beta gene expression during the rat estrous cycle. 


\section{Materials and Methods}

\section{Animal Protocol}

Adult female Sprague-Dawley rats were maintained in controlled lighting (14h of light; lights on at $0600 \mathrm{~h})$, temperature $\left(23^{\circ} \mathrm{C}\right)$ with food and water ad libitum. Vaginal smears were taken for 2 weeks and only rats that exhibited at least 2 consecutive 4-day cycles were used. Groups of rats $(\mathrm{n}=5-11)$ were decapitated at $3 \mathrm{~h}$ intervals throughout the cycle and hourly between 1000 and $2400 \mathrm{~h}$ on proestrus. Trunk blood was collected and sera stored at $-20^{\circ} \mathrm{C}$. Anterior pituitaries were removed, snap frozen and stored at $-70^{\circ} \mathrm{C}$.

\section{Radioimmunoassays (RIAs)}

Serum inhibin levels were measured using an antibody generated against the synthetic rat inhibin alpha 1-27 (Tyr 27 ) peptide fragment as previously described (16). The radioligand and standard used in the RIA were the same synthetic peptide. Results were expressed as femtomoles/ml (as determined from the $32 \mathrm{KD}$ inhibin molecule). Serum FSH was measured by RIA using NIADDK reagents and RP-1 as standard. Serum LH was measured in samples on proestrus in order to determine the onset and duration of the proestrus LH surge (using NIADDK reagents and RP-1 as standard).

\section{mRNAAssessment}

Pituitaries were homogenized under sterile conditions and cytoplasmic RNA extracted with a phenol-chloroform-isoamyl alcohol mixture $(100: 100: 1)$ and quantitated by absorbance at 260 $\mathrm{nm}$. Nuclear pellets were sonicated and DNA measured by fluorometric assay. RNA samples were spotted on nitrocellulose filters $(8 \mathrm{ug} / \mathrm{spot})$ in duplicate and hybridized to saturating amounts of $32 \mathrm{P}$ labeled FSH beta cDNA probe (generously provided by Dr. Richard A. Maurer, Univ of Iowa) as described previously (17). FSH beta mRNA levels were expressed as femtomoles of cDNA bound/100 ug pituitary DNA as previously reported (15).

\section{Statistical Analysis}

Data was analyzed using one way analysis of variance with differences between timepoints determined by Duncan's multiple range test.

\section{$\underline{\text { Results }}$}

Figure $1 \mathrm{C}$ shows serum inhibin concentrations during the rat estrous cycle. Inhibin levels remained stable between $0500 \mathrm{~h}$ of diestrus through the late morning of proestrus, and decreased abruptly between $1100 \mathrm{~h}$ and $1600 \mathrm{~h}$. This decline was followed by a transient rise ( 2 fold vs $1300 \mathrm{~h}$ ) in serum inhibin between 1700 and $1900 \mathrm{~h}$ of proestrus. Serum inhibin declined during the late evening of proestrus and remained relatively stable throughout estrus until the afternoon of metestrus. During the evening of metestrus, inhibin concentrations rose reaching a peak ( 2 fold increase vs morning of metestrus) at $0200 \mathrm{~h}$ of diestrus.

Serum FSH concentrations are shown in Figure 1A. On proestrus, serum FSH began to increase at $1800 \mathrm{~h}$ and peaked at $2000 \mathrm{~h}$, coincident with the decline in serum inhibin levels. Serum FSH fell on late proestrus - early estrus before the secondary rise at $0500 \mathrm{~h}$ of estrus. Serum FSH remained stable during the later portion of estrous and through metestrus and diestrus. The onset and duration of the proestrus LH surge is shown as a horizontal line above the serum FSH data in Figure 1A. Serum LH began to rise $(>200 \mathrm{ng} / \mathrm{ml})$ between 1600 and $1700 \mathrm{~h}$ and remained elevated $(>2100 \mathrm{ng} / \mathrm{ml})$ through $2100 \mathrm{~h}$. The peak of the LH surge $(2440 \pm 1273 \mathrm{ng} / \mathrm{ml}$ ) was seen at $1800 \mathrm{~h}$. FSH beta mRNA concentrations (Fig 1B) rose during the FSH surge beginning at $2000 \mathrm{~h}$ (as serum inhibin levels were declining) and reached a peak at $0200 \mathrm{~h}$ of estrus. A second increase in FSH beta mRNA began at $2300 \mathrm{~h}$ of estrus and continued through the late afternoon of metestrus. FSH beta mRNA declined as serum inhibin levels were increasing during the evening of metestrus. 

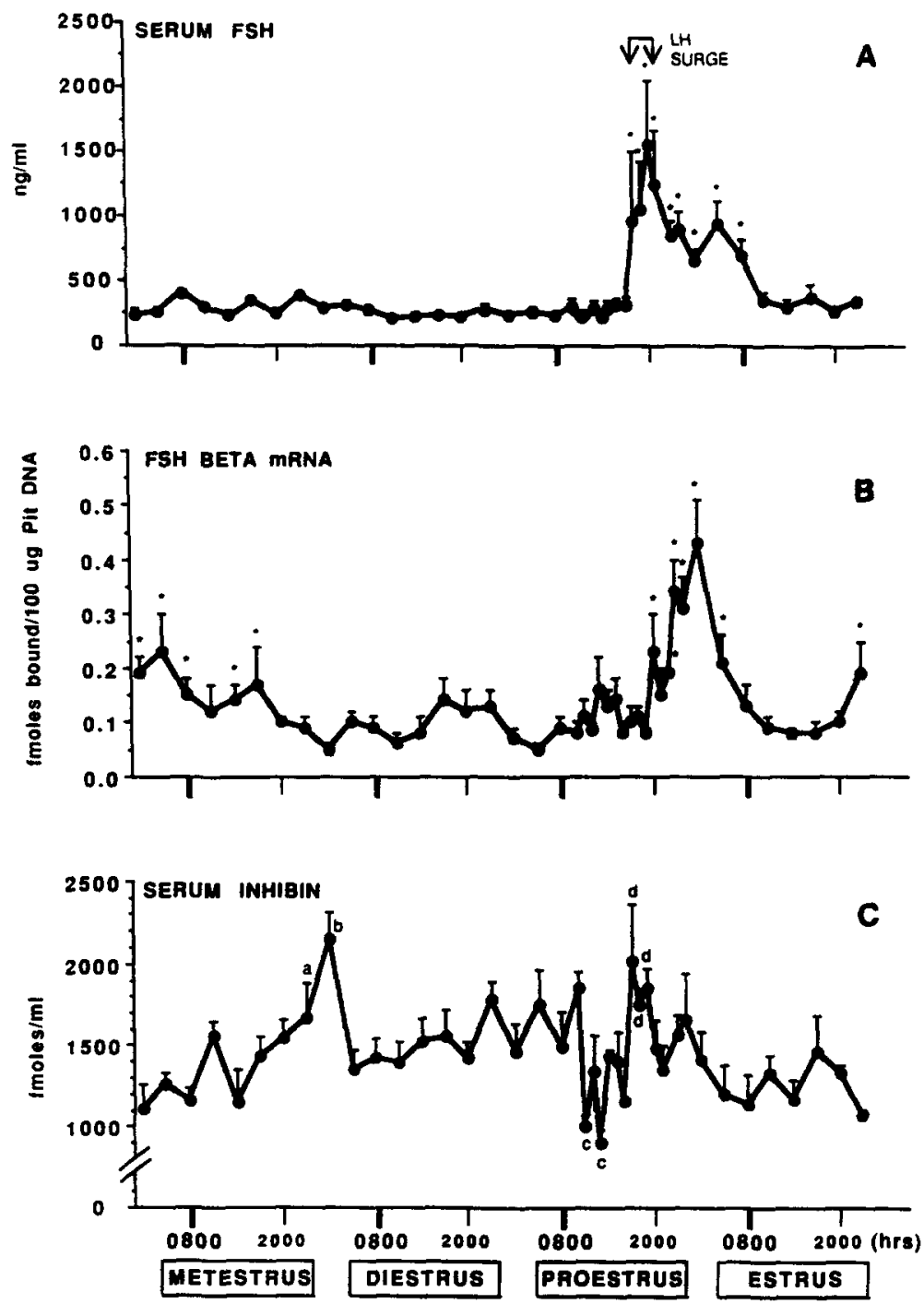

Fig. 1

Serum FSH (A), FSH beta mRNA (B) and serum inhibin (C) concentrations during the rat estrous cycle. Mean \pm SEM for each group (5-11 rats/group) are shown. The horizontal line between the arrows above serum FSH values (1A) show the timing and duration of the proestrus LH surge. Panel A: ${ }^{*} \mathrm{P}<0.05$ vs $0200-1200 \mathrm{~h}$ of proestrus. $\mathrm{B} * \mathrm{P}<0.05$ vs all timepoints with mean values less than or equal to $0.1 \mathrm{fmol} \mathrm{cDNA}$ bound/100 ug pit DNA. Panel C: a $\mathrm{P}<0.05 \mathrm{vs}$ $0200-0800 \mathrm{~h}$ of metestrus, $b_{\mathrm{P}}<0.05$ vs $0500-2000 \mathrm{~h}$ of diestrus; ${ }^{c} \mathrm{P}<0.05$ vs $0200-1000$ h of proestrus; $d \mathrm{P}<0.05$ vs $1100-1600 \mathrm{~h}$ of proestrus. The FSH beta mRNA concentrations have been previously reported (Endocrinology $123: 2149,1988$ ) and are shown here for comparison with the permission of the Editor. 


\section{Discussion}

The present study describes the first characterization of the relationships between serum inhibin, FSH secretion and FSH beta gene expression throughout the rat estrous cycle. The data agree with recent findings on more limited studies of proestrus $(18,19)$ which showed that serum inhibin increases during the evening of proestrus before falling on late proestrus-early estrus. The timecourse of this decline in serum inhibin has been shown to parallel observed decreases in ovarian inhibin alpha and beta subunit mRNAs (20). Data from other studies $(21,22)$ suggest that the decrease in serum inhibin during late proestrus may be regulated by the late afternoon gonadotropin surges (either LH, FSH or both) and could be responsible for the secondary FSH surge seen during the early morning of estrus. It is of interest that this decrease in serum inhibin levels on late proestrus was coincident with the initial FSH surge-related rise in FSH beta mRNA concentrations and preceded the FSH beta mRNA peak ( $0200 \mathrm{~h}$ of estrus) by $6 \mathrm{~h}$. Serum inhibin also showed a transient decrease during the late morning-early afternoon of proestrus. The physiological significance of this decrease is uncertain, but could relate to previously observed changes in serum estradiol $\left(E_{2}\right)$ concentrations on proestrus. Serum $E_{2}$ levels have been shown to decline on the afternoon of proestrus $(1,3,18)$. Other studies $(23,24)$ have shown that $E_{2}$ can stimulate inhibin secretion as well as inhibin subunit gene expression, suggesting a possible paracrine regulatory mechanism. It is possible that a fall in ovarian $E_{2}$ concentrations might reduce inhibin synthesis and secretion resulting in the transient decrease in serum inhibin during the early afternoon of proestrus.

Beginning on late estrus through the evening of metestrus, FSH beta subunit mRNA levels were elevated (approx 2 fold). This was not coupled to a measurable increase in FSH secretion similar to previously described increases for pituitary alpha and LH beta subunit mRNAs on diestrus (25). The late metestrus decrease in FSH beta mRNA levels was coincident with a rise in serum inhibin levels. This increase in serum inhibin during metestrus was also observed in a recent study by Hasegawa and colleagues $(18)$. In vitro studies have shown $(12,14)$ that inhibin can rapidly and selectively suppress FSH beta gene expression in gonadotroph cells, suggesting that the metestrus rise in inhibin secretory activity could be responsible for the decrease in FSH beta mRNA levels.

During the early morning of diestrus, serum inhibin concentrations decreased and remained stable for a period of $29 \mathrm{~h}$. Approximately one half of the developing follicles recruited as a result of the proestrus FSH surge become atretic during metestrus (26). Since the levels of inhibin in blood appear to be positively correlated to the number of available follicles (27) the decline in serum inhibin on early diestrus might reflect the loss of viable follicles.

Recent studies provide support for a physiological role of the rise in serum inhibin during late metestrus-early diestrus (19). Removal of endogenous inhibin activity by administration of inhibin antisera on metestrus and diestrus resulted in a rise in serum FSH, a 2 fold increase in ovulation rate and a 2 fold increase in the number of conceptuses in animals that were mated. These results suggest that the rise in inhibin between metestrus and diestrus may provide a protective effect against overstimulation of the ovary by FSH.

In summary, alterations in serum inhibin concentrations occur during the rat estrous cycle. The data provide support for an inverse relationship between serum inhibin and FSH secretory activity and FSH beta gene expression. However, further studies are required to delineate the exact physiological interactions between inhibin and FSH synthesis and secretion, and await the availability of recombinant inhibin for in vivo studies.

\section{Acknowledgements}

Materials and iodinations provided by Standards and Reagents Core, RSP Program, University of Michigan, through the National Hormone and Pituitary Program (Univ Maryland School of Medicine), NIDDK, NIH. The authors wish to thank Linda McCrate for preparing this manuscript. 
Supported by USPHS Grants: ${ }^{1} \mathrm{HD} 07269$ to AC Dalkin, ${ }^{2} \mathrm{HD} 23736, \mathrm{HD} 11489$ to JC Marshall, ${ }^{3} \mathrm{HD} 13527$ to WW Vale, and conducted in part by the Clayton Foundation for Research, California Division. WV is a Clayton Foundation Investigator.

\section{References}

1. R.L. BUTCHER, W.E. COLLINS and N.W. FUGO, Endocrinology 94 1704-1708 (1974)

2. M.S. SMITH, M.E. FREEMAN and J.D. NEILL, Endocrinology 96 219-226 (1975)

3. L.G. NEQUIN, J. ALVAREZ and N.B. SCHWARTZ, Biol Reprod 20 659-670 (1979)

4. R.T. SAVOY-MOORE, N.B. SCHWARTZ, J. DUNCAN and J.C. MARSHALL, Science 209 941-943 (1980)

5. Y. HASEGGAWA, K. MIYAMOTO, C. YAZAKI and M. IGARASHI, Endocrinology 109 130-134 (1981)

6. T.P. CONDON, D. HEBER, J.M. STEWART, C.H. SAWYER and D.I. WHITMOYER, Neuroendocrinology 38 357-362 (1984)

7. N.B. SCHWARTZ and C.P. CHANNING, Proc Natl Acad Sci USA 74 5721-5725 (1977)

8. R.T. SAVOY-MOORE and N.B. SCHWARTZ, Reproductive Physiology:, RO Groep (ed), Vol 3 203-248, University Park Press, Baltimore (1980)

9. N. LING, S.Y. YING, N. UENO, F. ESCH, L. DENOROY and R. GUILLEMIN, Proc Natl Acad Sci USA 82 7217-7221 (1985)

10. P.G. FARNWORTH, D.M. ROBERTSON, D.M. deKRESTER and H.G. BURGER, Endocrinologgy 122 207-213 (1988)

11. F. KOTSUII, S.J. WINTERS, H.S. KEEPING, B. ATTARDI, H. OSHIMA and P. TROEN, Endocrinology 122 2796-2802 (1988)

12. B. ATTARDI, H.S. KEEPING, S.J. WINTERS, F. KATSUJI, R.A. MAURER and P. TROEN, Mol Endocrinol 32 280-287 (1989)

13. J.E. MERCER, J.A. CLEMENTS, J.W. FUNDER and I.J. CLARKE, Mol Cell Endocrinol 53 251-256 (1987)

14. R.S. CARROLL, A. CORRIGAN, S.D. GHARIB, W.W. VALE and W.W. CHIN, Mol Endocrinol 3 1969- (1989)

15. G.A. ORTOLANO, D.J. HAISENLEDER A.C. DALKIN, S.A. ILIFF-SIZEMORE, T.D. LANDEFELD, R.A. MAURER and J.C. MARSHALL, Endocrinology 123 21492151 (1988)

16. C. RIVIER, S. CAJANDER, J. VAUGHAN, A.J.W. HSUEH and W. VALE, Endocrinology 123 120-125 (1988)

17. S.S. PAPAVASILIOU, S.M. ZMEILI, L. HERBON, J. DUNCAN-WELDON, J.C. MARSHALL and T.D. LANDEFELD, Endocrinology 119 6991-698 (1986)

18. Y. HASEGAWA , K. MIYAMOTO and M. IGARASHI, J Endocrinol 121 91-100 (1989)

19. C. RIVIER and W. VALE, Endocrinology 125 152-157 (1989)

20. T.K. WOODRUFF, J. D'AGOSTINO, N.B. SCHWARTZ and K.E. MAYO, Science 239 1296-1299 (1988)

21. C. RIVIER, V. ROBERTS and W. VALE, Endocrinology 125 876-882 (1989)

22. T.K. WOODRUFF, J. D'AGASTINO, N.B. SCHWARTZ and K.E. MAYO, Endocrinology 124 2193-2199 (1989)

23. C. RIVIER and W. VALE, Endocrinology 124 195-198 (1989)

24. I.M. TURNER, P.T.K. SAUNDERS, S. SHIMASAKI and S.G. HILLIER, Endocrinology 125 2790-2792 (1989)

25. S.M. ZMEILI, S.S. PAPAVASILIOU, M.D. THORNER, W.S. EVANS, J.C. MARSHALL, T.D. LANDEFELD, Endocrinology 119 1867-1869 (1986)

26. A.N. HIRSHFIELD, Biol Reprod 31 52-58 (1984)

27. J. D'AGOSTINO, T. WOODRUFF, K. MAYO and N. SCHWARTZ, Endocrinology $124310-317$ (1989) 